\title{
CHROMATOGRAPHIC PURIFICATION OF HUMAN SERUM ACCELERATOR GLOBULIN ${ }^{1}$
}

\author{
BY FREDERICK M. COX, GERARD F. LANCHANTIN, AND ARNOLD G. WARE \\ (From the Department of Biochemistry and Nutrition, University of Southern California School \\ of Medicine, and the Laboratory Division of the Los Angeles County Hospital, \\ Los Angeles, Calif.)
}

(Submitted for publication July 26, 1955 ; accepted August 24, 1955)

There appears to be general agreement among investigators of blood clotting regarding the existence in plasma of a heat-labile factor which potentiates the action of thromboplastin as a prothrombin converting agent (1). This clotting agent appears to be a protein which is not adsorbed on barium sulfate and which will correct the prolonged prothrombin time of aged, oxalated, human plasma. There is a lack of agreement about its nomenclature; the terms accelerator globulin (2), proaccelerin (3), Factor V (4), and labile factor (5) being used predominately.

Considerable confusion exists about the presence and characteristics of accelerator globulin in serum. This is partly due to the fact that another accelerator has been identified in serum which can be readily removed by barium sulfate adsorption. This factor is most frequently referred to as SPCA (6), proconvertin (7), stable factor (8) or co-thromboplastin (9). ${ }^{2}$ Barium sulfate treatment of bovine serum does not remove the accelerator globulin (AcG) activity. In fact, after barium sulfate adsorption, considerably more AcG activity is demonstrable in bovine serum than in bovine plasma. Similarly, it is possible to produce a significant increase in plasma AcG activity by treatment of bovine plasma with purified thrombin. To explain these phenomena, it was proposed by Ware, Murphy, and Seegers (11) that thrombin causes activation of AcG. Two forms of AcG were suggested to exist, plasma $A c G$ and serum AcG. It seems probable that the AcG in plasma exists in a relatively inert form

1 This investigation was supported by grants from the U. S. Public Health Service (H-1649 C4) and the Research and Development Board, Office of the Surgeon General, Department of the Army, (Da-49-007-MD-193).

2 These and other synonyms have been listed by the Subcommittee on Nomenclature of Nonprothrombin Plasmin Factors of the Josiah Macy, Jr. Foundation (10). and that serum AcG results from the action of thrombin on the plasma precursor (11).

Proposal of the existence of two forms of AcG with thrombin as mediator has been accepted by some investigators. Owren's proaccelerin is synonymous with plasma AcG; accelerin, with serum AcG (12). Others have not accepted this hypothesis on the basis that the accelerator activity produced with thrombin is probably due to factors other than AcG $(13,14)$. This is not surprising because of the complex reactions involved and because a different situation exists in human serum. There appears to be minimal AcG activity in human serum, all of which is removed with barium sulfate.

The AcG activity in human plasma and serum was investigated recently by Lewis and Ware (15). They found that thrombin activation of human plasma AcG proceeded in much the same manner as bovine. However, shortly after addition of the thrombin, the serum AcG activity diminished to a level which was less than that of the original plasma. This was apparently the result of an inhibitor which was isolated in crude form. Furthermore, they demonstrated that purified plasma AcG, of human origin, which had been adsorbed by barium sulfate, developed a 10 to 30 -fold increase in activity on incubation with small amounts of purified thrombin. Since the thrombin had also been subjected to barium sulfate adsorption this experiment removes any reasonable doubt that the activation of plasma AcG by thrombin is due to the evolution of SPCA or convertin.

Thus, it appears that thrombin activates AcG of both bovine and human origins. Plasma precursors from both species as well as the activated bovine serum AcG are not adsorbed appreciably on barium sulfate. However, serum AcG of hu- 
man origin is readily adsorbed. Therefore, it seems that in the human species, plasma AcG and serum AcG parallel the adsorption characteristics of thrombin and prothrombin, respectively.

Some success has been achieved in this laboratory in the isolation of human plasma AcG (16) but the products obtained were of extreme lability, low specific activity and did not lend themselves to adequate study of further purification procedures. In this communication, a method is described for the isolation of serum AcG of high specific activity by chromatography on an ion exchange resin and additional evidence is provided for the activation of AcG by thrombin.

\section{METHODS AND MATERIALS}

\section{Assay methods}

Accelerator globulin. AcG activity was measured by the one-stage method of Lewis and Ware (17). It is defined as the heat-labile property of plasma which accelerates the clotting of aged, oxalated human plasma in the presence of tissue thromboplastin and calcium ions. An arbitrary unit of AcG activity was selected which is equivalent to that displayed by $0.01 \mathrm{ml}$. of freshly-collected, citrated human plasma. Bovine plasma has been found to exhibit eight to nine times this amount of activity.

Thrombin. Thrombin was assayed by measuring the clotting time of fibrinogen standardized according to that used in the two-stage analysis of prothrombin (18).

Protein. Protein was measured by the modified FolinCiocalteu method of Daughaday, Lowry, Rosebrough, and Fields (19).

\section{Materials}

Thrombin preparations. Parke, Davis \& Company, Thrombin Topical, was reconstituted and rendered free of prothrombin by adsorption with barium sulfate (15). Following this, the solutions were made up to 250 units per $\mathrm{ml}$. in 50 per cent glycerol and stored at $0^{\circ} \mathrm{C}$. Prior to use, the thrombin was diluted with 0.9 per cent sodium chloride to give the desired activity. ${ }^{3}$ These crude thrombin products were employed in the majority of our preparative procedures for the activation of AcG.

Purified thrombin of human and bovine origin was employed in some preparations. Human thrombin was obtained by activation of purified human prothrombin products (16) with 25 per cent sodium citrate (20).

3 Ampoules of Parke-Davis Topical Thrombin are guaranteed to contain at least a total of 5,000 Iowa units. In most instances they contain appreciably more as well as large amounts of unconverted prothrombin, thromboplastin, calcium and extraneous protein. However, it was found to be of sufficient quality for use in the procedure to be described.
Bovine thrombin was derived by similar methods from a purified prothrombin preparation (No. 530818 having approximately 2,530 2-stage units per mg. tyrosine) kindly supplied by Dr. Walter $H$. Seegers of Wayne University Medical School, Detroit. The reaction products obtained by activation of prothrombin with sodium citrate were further purified by zone electrophoresis on a starch block (21) from which a single electrophoretic component having thrombin activity was isolated.

Preparation of resin and column. Rohm and Haas Amberlite IR-400, a strongly basic polystyrene quaternary amine type resin having a mesh size of $16-30$ and charged in the chloride cycle, was employed for the chromatographic separation and purification of serum AcG. One hundred grams of anion resin, without prior purification, were triturated with approximately 1 liter of an aqueous 10 per cent solution of sodium chloride for 1 hour. After decantation of the salt solution, the resin was washed with several liters of distilled water until the washings were free of chloride ion. This process was repeated and the charged resin stored in the moist state until ready for use. Amberlite IR-400 anion resins with three different lot numbers were employed in the experiments to be described and all proved satisfactory.

The chromatographic column was prepared by pouring an aqueous suspension of resin into a $1.2 \times 36 \mathrm{~cm}$. glass column fitted with a small quantity of glass wool at the tapered end to prevent leakage of the resin. The glass column was filled with resin to a height of $24 \mathrm{~cm}$. and was then washed with $10 \mathrm{ml}$. portions of water to insure uniform packing. This procedure permitted a relatively constant flow time through the resin and no detectable bubble formation. It was found desirable to pack the top of the column with approximately $2 \mathrm{~mm}$. of finely meshed glass beads to prevent agitation of the uppermost resin particles by the influent. The hold-up volume of the resin was approximately 7 to $8 \mathrm{ml}$.

Regeneration of the resin was accomplished by triturating $100 \mathrm{gm}$. of IR-400 with $1 \mathrm{~L}$. of $6 \mathrm{~N}$ sodium hydroxide, washing copiously with water until the wash solution approximated a neutral $\mathrm{pH}$, and recharging with 10 per cent sodium chloride in the manner described above.

Preparation of crude plasma AcG. Crude plasma AcG was prepared by a modification of the method of Lewis and Ware (16) with the omission of the salt fractionation procedures. Blood was taken from putatively normal donors by venipuncture and mixed immediately in a proportion of 9 to 1 with $0.1 \mathrm{M}$ sodium citrate. After separation of the cells by centrifugation at $2,500 \mathrm{G}$. for 10 minutes, the supernatant plasma was rendered free of prothrombin by successive adsorptions on barium citrate and barium sulfate precipitates. In this technic, $2 \mathrm{ml}$. of $1.0 \mathrm{M}$ barium chloride were added slowly to $20 \mathrm{ml}$. of plasma with constant agitation at $0^{\circ}$ C. After standing in the cold for 10 minutes, the barium citrate precipitate was removed by centrifugation at $0^{\circ} \mathrm{C}$. for 15 minutes at $33,000 \mathrm{G}$. to the supernatant fluid thus obtained, $2 \mathrm{ml}$. of a $1.0 \mathrm{M}$ solution of sodium sulfate 


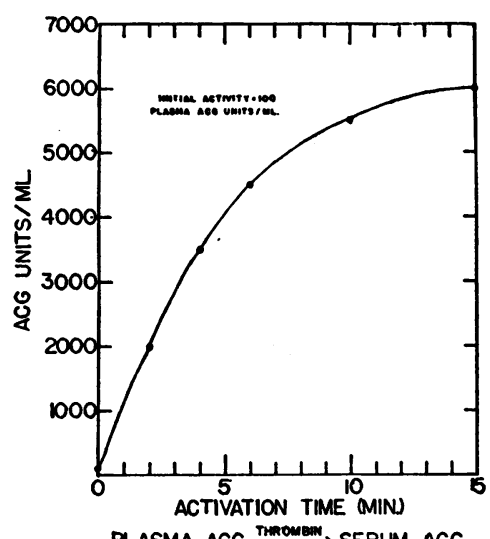

PLASMA ACG $\stackrel{\text { Thomem }}{\longrightarrow}$ SERUM ACG

Fig. 1. The Activation of Plasma AcG to Serum AcG in the Acid Precipitate by Addition of THROMBIN

To $10 \mathrm{ml}$. of acid precipitate at $37^{\circ} \mathrm{C} ., 1 \mathrm{ml}$. of thrombin solution containing 50 units per $\mathrm{ml}$. was added. At intervals, $0.1-\mathrm{ml}$. aliquots of the incubation mixture were taken and tested for AcG activity. (The points on the above curve represent the average of twelve experiments.)

were added slowly in the cold and the barium sulfate subsequently separated by high speed centrifugation.

After this treatment with barium citrate and barium sulfate, the plasma obtained was devoid of detectable amounts of prothrombin but contained most of its plasma AcG and fibrinogen, as well as antihemophilic globulin and plasminogen. It was then diluted 20 times with distilled water at room temperature and adjusted to $\mathrm{pH} 5.5$ with the slow addition of 1 per cent acetic acid and constant stirring. The precipitate formed was harvested by centrifugation in the cold for 10 minutes at high speed and was subsequently dissolved in onehalf of its original plasma volume with 0.9 per cent sodium chloride, $\mathrm{pH} 7.0$ to 7.2. This material will be identified henceforth in this paper as the acid precipitate.

The acid precipitate obtained in the above manner was usually found to contain approximately 50 per cent of the original AcG activity of the starting plasma (i.e., 100 units per $\mathrm{ml}$.) and had a protein concentration of 6 to 8 mg: per $\mathbf{m l}$.

\section{RESULTS}

\section{Activation of plasma $A c G$ in the acid precipitate}

The activation of plasma AcG to serum AcG by incubation of the acid precipitate with thrombin is diagrammed in Figure 1. Upon the introduction of thrombin to the acid precipitate, fibrinogen clotted out. The fibrin thus formed was removed mechanically. With most preparations, the AcG activity was increased 50 to 60 times by the addition of thrombin at a concentration of 5 units per ml.
After 15 to 20 minutes of activation, the AcG activity reached a maximum and thereafter decreased appreciably. The drop in activity is probably due to the fact that thrombin not only elaborates a more active accelerator but also destroys it (22). This was found to be particularly true when concentrations of thrombin greater than 5 units per $\mathrm{ml}$. of acid precipitate were used or when highly active electrophoretically purified thrombin preparations were employed (Figure 2). Fortunately for our purposes, the thrombin destruction of AcG was found to be minimized when the incubation mixture was subjected to chromatographic separation of serum AcG.

\section{Chromatographic separation and purification of serum $A c G$}

After the AcG activity of the incubation mixture reached a maximum, the crude serum AcG product thus obtained had an activity of 5 to 6,000 units per $\mathrm{ml}$. and a protein concentration of approximately 5 to $6 \mathrm{mg}$. per $\mathrm{ml}$. It was immediately placed on the Amberlite IR- 400 column and allowed to percolate through the resin at a flow rate of approximately $1.5 \mathrm{ml}$. per min. The column was then washed with distilled water or with 0.9 per cent sodium chloride, $\mathrm{pH}$ 6.0, until the eluates gave negative tests for protein and AcG activity. A volume of wash solution equivalent to the initial volume placed on the column was found to be sufficient for this purpose. Resolution of the AcG activity was achieved by the addition of 3.0

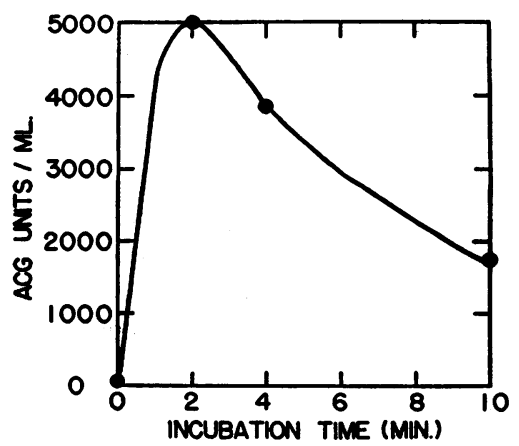

Fig. 2. Activation of Acid Precipitate with Human THROMBIN

Conditions of the experiment similar to Figure 1. Two hundred units of human thrombin, derived by citrate activation of purified human prothrombin, were added to $10 \mathrm{ml}$. of the incubation mixture.

The initial AcG activity was 100 units per $\mathrm{ml}$. 
per cent sodium chloride to the resin column. All effluents were collected as 1-ml. samples and tested for AcG activity as well as protein. Two typical experiments are presented in Figures 3 and 4.

It is obvious from Figure 3 that a large portion of the protein and some AcG activity pass through the column and are washed out with water. Upon introduction of 3 per cent sodium chloride to the influent, a front of AcG activity with only minimal amounts of protein becomes apparent. In

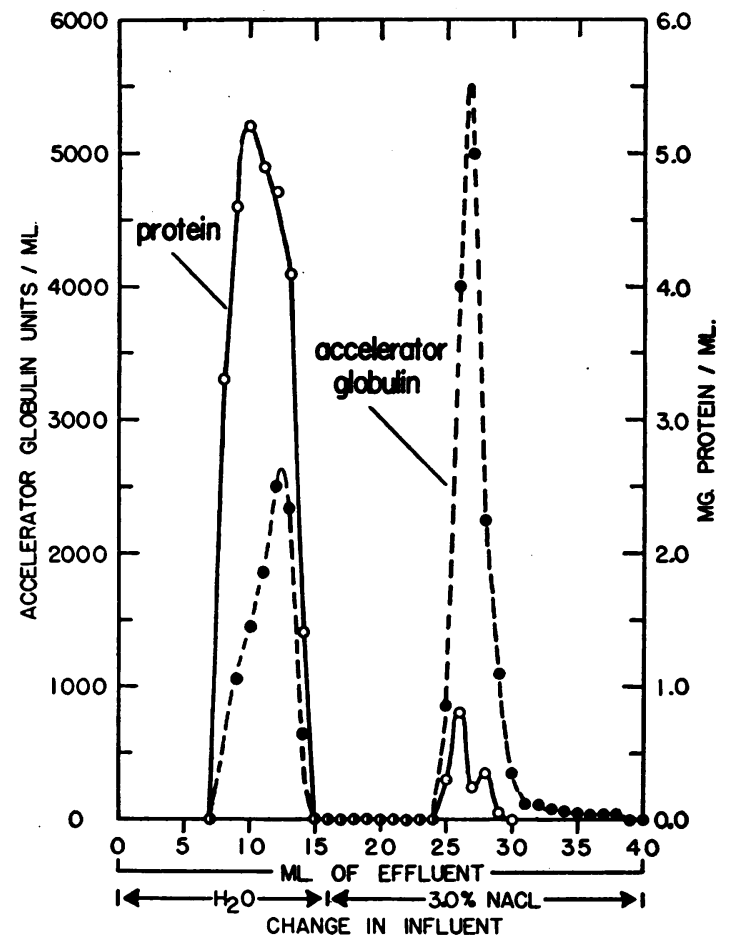

Fig. 3. Chromatographic Separation of Serum AcG from the Acid Precipitate Employing Water IN THE INITIAL Wash SOlution

Solution before chromatography

Volume $\quad 7.0 \mathrm{ml}$.

AcG units/ml. 5,750

Protein/ml. 4.94

Specific activity 1.160

Effluent volumes

First peak

Volume $1 \mathrm{ml}$. (No. 12)

AcG units/ml. 2,500

Second peak

Protein $/ \mathrm{ml}$.

$$
4.7
$$

Specific

532 units/mg. protein

Volume $1 \mathrm{ml}$. (No. 27)

5,000

0.28

17,850

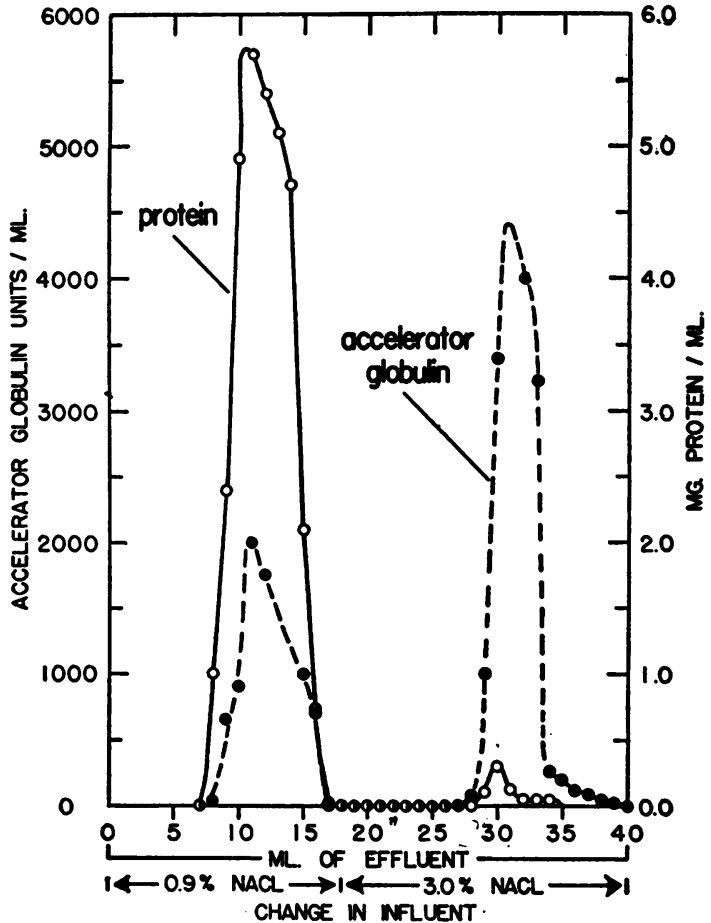

Fig. 4. Chromatographic Separation of Serum AcG FROM THE ACID PRECIPITATE EMPLOYING 0.9 PER CENT Sodium Chloride in the InItial Wash SOlution

Solution before chromatography

Volume $\quad 8 \mathrm{ml}$. $\quad$ Protein $/ \mathrm{ml}$. 5.5

AcG units/ml. $6,150 \quad$ Specific activity 1.118

Effuent volumes

\begin{tabular}{|c|c|c|}
\hline & First peak & Second peak \\
\hline Volume & $1 \mathrm{ml}$. (No. 11) & $1 \mathrm{ml}$. (No. 32) \\
\hline AcG units/ml. & 2,000 & 4,000 \\
\hline Protein/ml. & 5.7 & 0.05 \\
\hline Specific activity & $\begin{array}{r}351 \text { units/mg. } \\
\text { protein }\end{array}$ & $\begin{array}{r}80,000 \text { units } / \mathrm{mg} \\
\text { protein }\end{array}$ \\
\hline
\end{tabular}

Protein $75 \%$

Activity $50 \%$

this experiment there are two protein components associated with the second peak while the AcG activity appears to reside somewhere between them. When the column is first washed with 0.9 per cent sodium chloride, one of these peaks of protein is eliminated and further purification of AcG results (Figure 4). However, the AcG obtained in this fashion is still contaminated with traces of extraneous protein since chromatography of the unactivated acid precipitate itself results in a small amount of protein in the second peak (Figure 5). Attempts to gain further removal of this contaminant by chromatography of the acid precipitate 


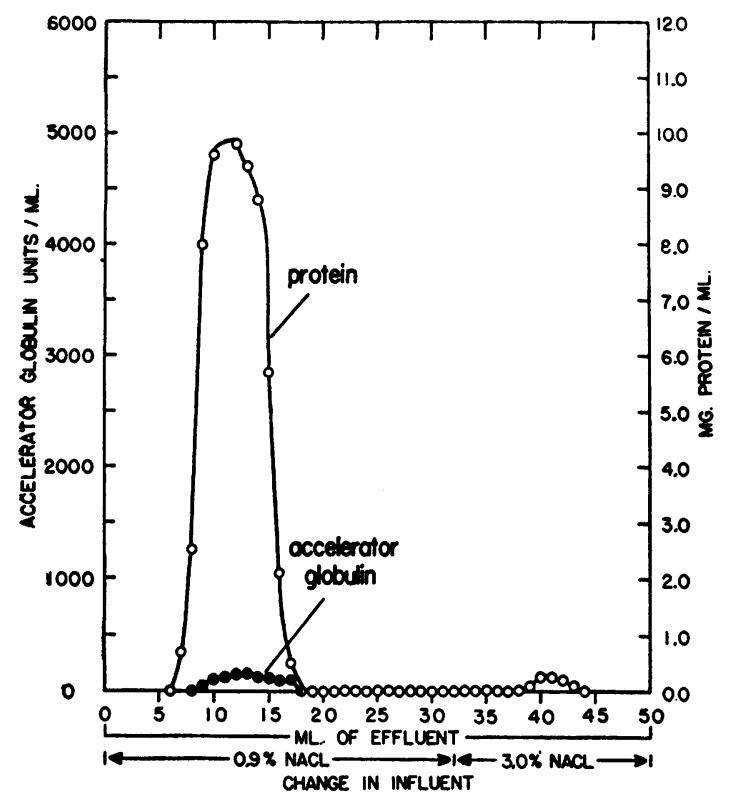

Fig. 5. Chromatographic Separation of the Unactivated Acid Precipitate

Solution before chromatography

$\begin{array}{llll}\text { Volume } & 8 \mathrm{ml} . & \text { Protein } / \mathrm{ml} . & 13.0 \mathrm{mg} . \\ \text { AcG units } / \mathrm{ml} . & 125 & \text { Specific activity } & 10\end{array}$

Effluent volumes

\begin{tabular}{lll} 
& \multicolumn{1}{c}{ First peak } & \multicolumn{1}{c}{ Second peak } \\
Volume & $1 \mathrm{ml}$. (No. 12) & $1 \mathrm{ml}$. (No. 41) \\
AcG units/ml. & 145 & 0 \\
Protein/ml. & 9.8 & 0.22 \\
Specific activity & 15 units $/ \mathrm{ml}$. & -
\end{tabular}

prior to thrombin activation and rechromatography have not been successful.

\section{Some chemical and physical properties of human serum $A c G$}

Ultra-violet absorption. Products obtained by the above chromatographic procedure were examined for ultra-violet absorption by employing a Beckman Model DU Quartz Spectrophotometer. Solutions of serum AcG in $0.1 \mathrm{~N} \mathrm{NaOH}$ and in $0.1 \mathrm{~N} \mathrm{HCl}$ gave an ultraviolet absorption curve between 320 and $220 \mathrm{mu}$ characteristic of a protein or polypeptide having a tyrosine peak between 275 to $280 \mathrm{mu}$.

Electrophoresis. Samples of human serum AcG having high specific activity were subjected to zone electrophoresis on filter paper using the method of Kunkel and Tiselius (23). Electrophoresis was carried out in $0.05 \mathrm{M}$ veronal buffer, $\mathrm{pH}$
8.6, $\mu=0.05$ for 20 hours at $0^{\circ} \mathrm{C}$. under a gradient of 8 volts per $\mathrm{cm}$. of paper. After drying, the strips were stained with 1 per cent bromphenol blue in ethyl alcohol saturated with mercuric chloride and then washed with 5 per cent acetic acid. Under these conditions, the majority of the material in the AcG sample migrated as one component with a mobility between that of beta and gamma globulin. Attempts to elute the AcG activity after sectioning the filter paper strip into $1 \mathrm{~cm}$. sections were unsuccessful.

Stability. After column chromatography, the AcG activity obtained in the resulting eluates was stable at room temperature for a period of several hours. By the following day after storage at $0^{\circ}$ C., however, the activity had deteriorated to less than one-third of the original. Some success has been achieved in stabilizing AcG activity by the addition of 50 per cent glycerol. An average of three typical experiments is presented in Figure 6. Concentrations of glycerol greater than 50 per cent tended to interfere with the assay procedure while concentrations below this level did not have as great a stabilizing influence. The use of $\mathrm{N}_{2}$, $\mathrm{CO}_{2}$, ascorbic acid, cysteine, glutathione, tosyl arginine methyl ester and beef ultrafiltrates in various concentrations were found to be ineffective in stabilizing AcG activity.

Dialysis. In attempting to free the AcG solu-

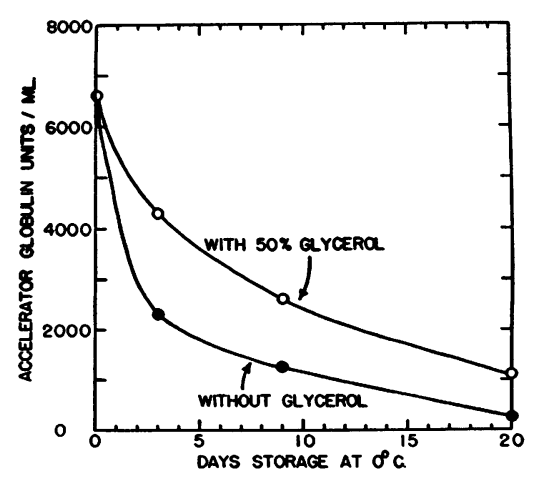

Fig. 6. The Stability to Storage at $0^{\circ} \mathrm{C}$. of $\mathrm{Hu}-$ man Serum AcG in the Presence and Absence of GLycerol

Effluent samples of high specific activity were obtained from three different chromatographic preparations. These were divided into controls and samples containing 50 per cent glycerol $(v / v)$ and stored in a refrigerator at $0^{\circ} \mathrm{C}$. Aliquots were taken and assayed for AcG activity at the time indicated. 


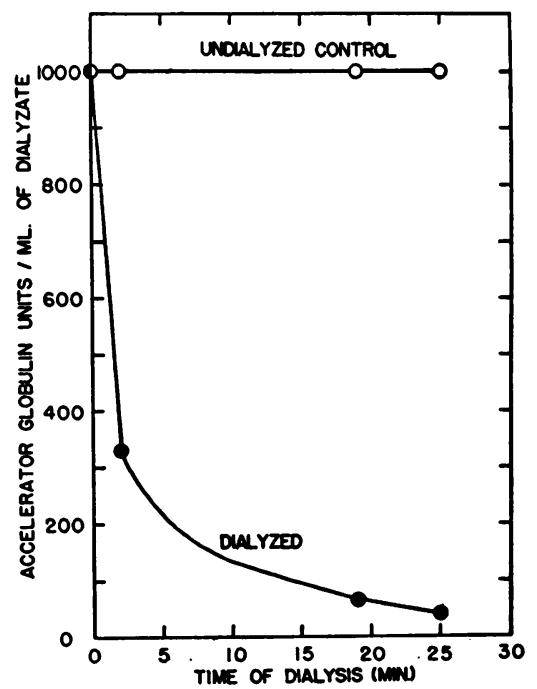

Fig. 7. The Effect of Dialysis on Human Serum AcG Activity

Three samples of chromatographically isolated AcG were pooled and diluted with 0.9 per cent sodium chloride to a volume having an activity of $1,000 \mathrm{AcG}$ units per $\mathrm{ml}$. Five $\mathrm{ml}$. of this solution were then subjected to rapid dialysis in a cellophane casing against $1 \mathrm{~L}$. of 0.9 per cent sodium chloride at room temperature in a mechanical dialyzer similar in construction to one recently reported (16). At intervals, $0.2-\mathrm{ml}$. aliquots of the dialysate, as well as a control sample of undialyzed solution, were taken and assayed for AcG activity.

tions of salts by dialysis, it was observed that the activity deteriorated rapidly. A typical experiment is diagrammed in Figure 7. Whether this loss of activity is due to destruction, diffusion of the AcG molecules through the membrane, or adsorption on the membrane, has not yet been definitely determined. Preliminary investigations provide evidence that the loss of serum AcG activity upon dialysis is the result of adsorption or destruction by the dialysis membrane.

\section{DISCUSSION}

The adsorption of serum AcG of human origin to an Amberlite resin appears to be unique. There is no appreciable adsorption of the plasma precursor to the resin under any conditions that we have been able to demonstrate. This provides evidence that the precursor, plasma $A c G$, is inert and that the activity it exhibits is generated in the assay procedure.

It seems rather unlikely that the thrombin-gen- erated accelerator activity can be attributed to any other clotting factor than the AcG itself. Under the conditions of these experiments, both the precursor and the thrombin have been exposed to barium sulfate adsorptions which should be adequate to remove other known accelerators. Furthermore, the thrombin continues to produce its effect on AcG even after the former has been subjected to extensive purification. Thrombin alone does not have a significant effect on the assay system in the concentration employed either before or after it has been run through the resin column. When thrombin is incubated with acid precipitated from aged human plasma with no demonstrable precursor activity, no accelerator activity is produced either before or following the resin treatment. Similar results are obtained with acid precipitates which have had their AcG activity destroyed by heating at $56^{\circ} \mathrm{C}$. for 30 minutes.

Crude plasma AcG products prepared as the acid precipitate from bovine plasma and then activated with thrombin in the manner described above, demonstrate no adsorptive properties for the resin and pass through the columns. This phenomenon lends further support to the thesis that bovine and human serum AcG are different in certain of their physical and chemical properties.

The exact nature of the chromatographic process whereby serum AcG is adsorbed to the resin column and eluted with salt solution is unknown. This mechanism doubtless involves a complicated series of events. In all probability, the adsorption phenomenon results from a saturation of the column with serum AcG while plasma AcG and unadsorbed serum AcG as well as thrombin are washed from the column at low salt concentrations. The resolution of the adsorbed serum AcG activity is probably due to a gradient type of elution process in which a concentration of salt is obtained in which serum AcG is more soluble and readily favors partition into the mobile phase. Since the conditions of the experiments probably do not operate under the requirements of reversibility required of true chromatography, the process more correctly conforms to Zittle's term, adsorption filtration (24). Such a situation would hold where separation is made of components more strongly adsorbed and components not adsorbed.

The chemical and physical properties of the serum AcG products obtained by the above chro- 
matographic method are indeed remarkable. They point up the fact that serum AcG is a trace substance capable of displaying a high degree of catalytic activity in amounts which almost defy chemical detection. In spite of the fact that the isolation procedure has resulted in about a thousand-fold purification of human AcG activity, it is quite likely that the products obtained are still not chemically pure. This is readily apparent in Figure 5 where it is seen that trace amounts of protein with no AcG activity are eluted from the column by 3 per cent sodium chloride. Repetitive chromatography of the final serum AcG product in attempts to achieve better purification have been unsuccessful. This is largely due to the instability of the preparation as well as the large amount of dilution necessary in the rechromatographic procedure.

It is interesting to speculate that the activated AcG of human origin may be a substance of low molecular weight, possibly approaching the dimensions of a polypeptide. This hypothetical reasoning stems from the fact that when plasma AcG is activated with thrombin, a number of fragments soluble in $\mathbf{5}$ per cent trichloracetic acid are split off the molecule concomitantly with the increase in accelerator activity (25). Also, the fact that serum AcG is adsorbed to an ion exchange resin, similar to other low molecular weight substances (24), as well as its loss of activity on dialysis, offers interesting avenues of approach in further investigations into the exact chemical nature of this substance.

\section{SUMMARY}

A method is described for the purification of human serum accelerator globulin by chromatography on Amberlite IR-400 columns. The technique involves the prior isolation of a crude plasma accelerator globulin preparation from freshly-collected, human, ACD plasma by barium citrate adsorption and acid precipitation. The material thus prepared is then activated to serum accelerator globulin followed by isolation on a chromatographic column.

Although the products thus prepared are not chemically homogeneous, they have the following properties :

1) An ultraviolet spectrum similar to a protein-peptide containing an aromatic amino acid.
2) A mobility between that of a beta and gamma globulin as measured by filter paper electrophoresis.

3) Loss of activity upon dialysis which may be due to destruction or adsorption.

4) Marked instability which can be somewhat minimized in the presence of 50 per cent glycerol.

\section{REFERENCES}

1. Stefanini, M., Basic mechanisms of hemostasis. Bull. New York Acad. Med., 1954, 30, 239.

2. Ware, A. G., and Seegers, W. H., Plasma accelerator globulin: partial purification, quantitative determination and properties. J. Biol. Chem., 1948, 172, 699.

3. Astrup, T., Blood clotting and related processes. Adv. Enzymol., 1950, 10, 1.

4. Owren, P. A., The coagulation of blood. Investigations on a new clotting factor. Gundersen, Oslo, Acta med. Scandinav., 1947, Supp. 194, 13.

5. Quick, A. J., Congenital hypoprothrombinaemia and pseudo-hypoprothrombinaemia. Lancet, 1947, 2, 379.

6. de Vries, A., Alexander, B., and Goldstein, R., A factor in serum which accelerates the conversion of prothrombin to thrombin: I. Its determination and some physiologic and biochemical properties. Blood, 1949, 4, 247.

7. Owren, P. A., Proconvertin, the new clotting factor. Scandinav. J. Clin. \& Lab. Invest., 1951, 3, 168.

8. Owen, C. A., Jr., Magath, T. B., and Bollman, J. L., Prothrombin conversion factors in blood coagulation. Am. J. Physiol., 1951, 166, 1.

9. Mann, F. D., and Hurn, M. M., The complex mechanisms of the Quick prothrombin test and the effect of Dicumarol. Am. J. Clin. Path., 1950, $20,225$.

10. Alexander, B., Flynn, J. E., Mann, F. D., Owren, P. A., and Seegers, W. H., Appendix: Synonymy of the nonprothrombin plasma factors involved in the conversion of prothrombin to thrombin. Tr. of the Fifth Conference on Blood Clotting and Allied Problems. Josiah Macy, Jr. Foundation, 1952, p. 329.

11. Ware, A. G., Murphy, R. C., and Seegers, W. H., The function of Ac-globulin in blood clotting. Science, 1947, 106, 618.

12. Owren, P. A., Prothrombin and accessory factors. Am. J. Med., 1953, 14, 201.

13. Owen, C. A., Influence of the stable conversion factor on blood clotting. Second Annual Symposium on Blood. Detroit, Wayne Univ., Jan. 17, 1953.

14. Quick, A. J., Hussey, C. V., and Epstein, E., Activation of thromboplastinogen by thrombin. Am. J. Physiol., 1953, 174, 123. 
15. Lewis, M. L., and Ware, A. G., The mechanism of action of human accelerator globulin and its relation to other clotting factors. Blood, 1954, 9, 520.

16. Lewis, M. L., and Ware, A. G., A simple procedure for separation of prothrombin and accelerator globulin from citrated human plasma. Proc. Soc. Exper. Biol. \& Med., 1953, 84, 636.

17. Lewis, M. L., and Ware, A. G., A one-stage method for the determination of accelerator globulin. Proc. Soc. Exper. Biol. \& Med., 1953, 84, 640.

18. Ware, A. G., and Seegers, W. H., Two-stage procedure for the quantitative determination of prothrombin concentration. Am. J. Clin. Path., 1949, 19, 471.

19. Daughaday, W. H., Lowry, O. H., Rosebrough, N. J., and Fields, W. S., Determination of cerebrospinal fluid protein with the folin phenol reagent. J. Lab. \& Clin. Med., 1952, 39, 663.

20. Seegers, W. H., McClaughry, R. I., and Fahey, J. L., Some properties of purified prothrombin and its activation with sodium citrate. Blood, 1950, 5, 421.

21. Lanchantin, G. F., Notrica, S. R., and Ware, A. G., Zone electrophoresis of prothrombin and thrombin. Federation Proc., 1955, 14, 241.

22. Ware, A. G., and Seegers, W. H., Serum Ac-globulin: formation from plasma Ac-globulin; role in blood coagulation; partial purification; properties; and quantitative determinations. Am. J. Physiol., 1948, 152, 567.

23. Kunkel, H. G., and Tiselius, A., Electrophoresis of proteins on filter paper. J. Gen. Physiol., 1951, 35, 89.

24. Zittle, C. A., Adsorption studies of enzymes and other proteins. Adv. Enzymol., 1953, 14, 319.

25. Lanchantin, G. F., and Ware, A. G., Note on the mechanism of activation of human plasma accelerator globulin by thrombin. Biochim. Biophys. Acta, 1955, Submitted for publication. 